\title{
Progress in phototherapy
}

\author{
University of São Paulo Medical School - São Paulo, Brazil
}

\begin{abstract}
The purpose of this article is to present a recent advance in phototherapy employed on newborn babies with jaundice. The efficacy of this treatment depends on the intensity of emitted light; it is believed that a dose between $6-12 \mathrm{~nm}$ is necessary. The usefulness of phototherapy in healthy, full-term infants is currently being questioned. Therefore, the adequate use of this therapy should be emphasized until a consensus is reached on its advantages and disadvantages.
\end{abstract}

UNITERMS: Phototherapy, newborn. Jaundice. Irradiation, efficacy.

\section{INTRODUCTION}

$\mathrm{E}$ ver since the introduction of phototherapy in 1958 by CRAMER, several models have been proposed. However, the physical and chemical alterations that occur in this form of therapy for newborn babies with jaundice were not evident until 1985, when McDONAGH and LIGHTER clarified these alterations using more advanced methodology.

Bilirubin, along with melanin and other heme group derived substances, are light-absorbing pigments. The visible spectrum, between 420 and 480 nanometers, is best absorbed by bilirubin.

When a photosensitive molecule absorbs light, it receives a determined quantity of luminous energy. After

\section{Address for correspondence:}

Maria Cristina Korbage de Araújo

Hospital Universitário - USP - Cidade Universitária

Av. Lineu Prestes, 2565 - Butantã

São Paulo/SP - Brasil - CEP 05508-900 receiving a photon, an electron will immediately move to a higher-energy orbit, thus becoming stimulated. This molecule may then react twice, forming the photoproducts. ${ }^{20}$

\section{Phototherapy causes two types of reaction}

1 - PHOTO-OXIDATION, which causes fragmentation in the structure of the bilirubin molecule.

2 - PHOTOISOMERIZATION, which transforms the unaltered bilirubin molecule into hydrosoluble isomers.

In PHOTO-OXIDATION, stimulated bilirubin (after the absorption of the photon) envelopes an oxygen molecule, which is then tranformed into a free radical capable of destroying native bilirubin, producing five renal excretion products. This is a slow reaction and occurs in small quantities, with dosages in the urine of between $2-9 \mathrm{mg} / 1 .{ }^{27}$

PHOTOISOMERIZATION is faster, and two different products can be formed which are eliminated by the liver: the structural isomer (lumirubin) and the configuration isomer. Lumirubin is formed by new bonds 
between the $\mathrm{CH}-\mathrm{CH} 2$ groups of one ring and the adjacent ring which involves the carbons from positions 2 and 7. Lumirubin is a stable product with a slow formation and rapid excretion, so great quantities do not accumulate in the circulation (varying from 1 to 14 percent); nevertheless it seems to be the main efficacy factor of phototherapy. ${ }^{6.8 .9}$ The formation of this isomer varies according to the quantity of energy emitted by the light. ${ }^{10}$ The configuration isomer is formed after a 180 degree rotation of the terminal ring on its axle, exposing its polar segment ( $\mathrm{NH}$ and $\mathrm{COOH})$ to the exterior of the molecule. This usually involves carbons 4 and 15 , whereas carbon 15 is one hundred times more involved than carbon 4 , and the product of this type of isomerization is almost exclusively isomer $4 \mathrm{Z}, 15 \mathrm{E} .^{27}$ This is formed rapidly, has a slow excretion, and accumulates in the circulation. It can be measured by high pressure liquid chromatography and corresponds to approximately 15 - 20 percent of the total bilirubin. ${ }^{6.10 .11 .12}$ The formation of this isomer does not depend on luminous intensity. ${ }^{6}$ However, this isomer is unstable, and can revert to the native bilirubin form, especially in the biliary channels. Figure 1 shows the reactions that are initiated by light.

\section{EFFICACY}

Efficient phototherapy reduces indirect bilirubin by $1-2$ mg every 24 hours of use, regardless of gestational

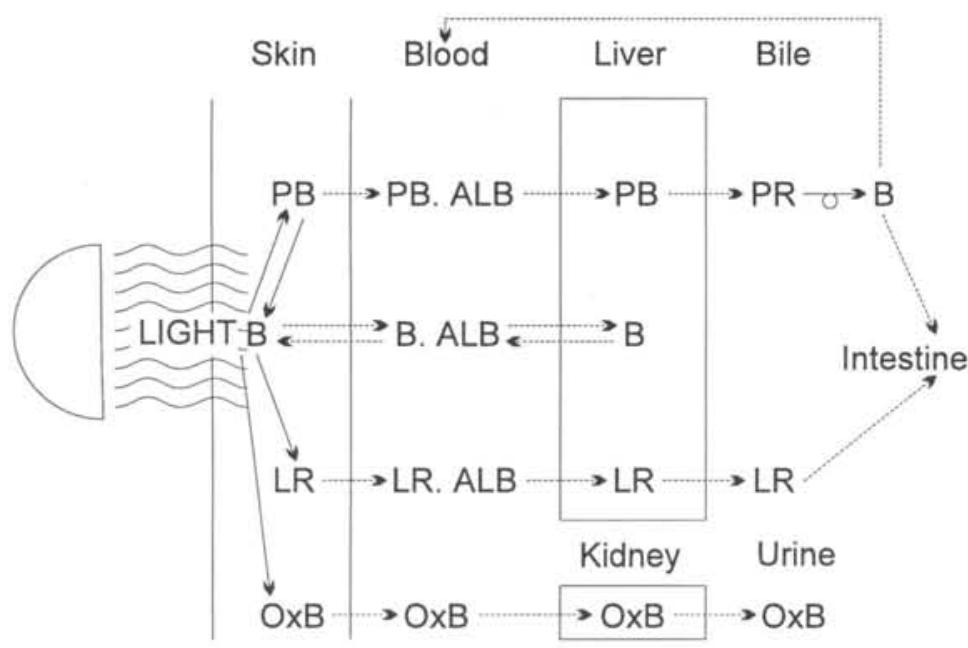

$\mathrm{B}=$ Bilirubin $\mathrm{Pb}=$ Photobilirubin $\mathrm{LR}=$ Lumirubin ALB $=$ Albumin $\mathrm{O} \times \mathrm{B}=$ Oxidizing Products

Figure 1 - Adapted from McDonagh \& Lightner, 1985. age. ${ }^{23}$ Recent studies ${ }^{6.10 .11}$ have evaluated the efficacy of phototherapy by measuring the photoproducts through high pressure liquid chromatography. However, the efficacy depends on the quantity of energy released by the light of the wave-length corresponding to bilirubin absorption. This energy is the irradiation, which depends on the numbers of lamps, type of light, time of use, distance from the source, and other interfering factors.

\section{IRRADIATION}

Irradiation of a surface within a determined range of the spectrum is expressed in microwatts $/ \mathrm{cm}^{2} / \mathrm{nm}(\mathrm{mw} /$ $\mathrm{cm}^{2} / \mathrm{nm}$ ). The greater the irradiation, the greater the efficacy of phototherapy. ${ }^{18}$ Several authors ${ }^{6,10,12.27}$ consider that irradiation around $6 \mathrm{mw} / \mathrm{cm} 2 / \mathrm{nm}$ is low intensity, and that irradiation around $12 \mathrm{mw} / \mathrm{cm} 2 / \mathrm{nm}$ is high intensity. COSTARINO et al. ${ }^{6}$ demonstrated that the formation of lumirubin is much higher with high-intensity irradiation; however, formation of the configuration isomer did not show any significant difference based on the type of irradiation used (Figs. 2 - 3). Increasing irradiation beyond the staturation point does not raise efficacy, and for MAISELS,${ }^{18}$ this point should be $23 \mathrm{mw} / \mathrm{cm} 2 / \mathrm{nm}$, while for TAN, ${ }^{31.18 .27}$ this point should be $40 \mathrm{mw} / \mathrm{cm} 2 /$ $\mathrm{nm}$. CARVALHO ${ }^{3}$ recently reported that phototherapy equipment in Rio de Janeiro does not emit more than 3 $\mathrm{mw} / \mathrm{cm} 2 / \mathrm{nm}$, which is much lower than that recommended by the literature, and concludes that newborn babies with jaundice are receiving irradiation, but are not being treated appropriately. It seems likely that a similar situation is occurring in other hospitals. ${ }^{28}$

Irradiation depends on factors such as:

\section{Number and Type of Lamps}

Traditional phototherapy equipment recommended by most of the studies $^{5.18 .27}$ requires 8 to 12 lamps. Irradiation is directly proportional to the number of lamps used in conventional phototherapy equipment. ${ }^{30}$ Most of the equipment used in our hospitals have only 6 fluorescent lamps, which directly interferes with the final result. ${ }^{4.28 .31}$

Recently, some services have used equipment with only one halogen lamp, irradiating in the $23 \mathrm{mw} / \mathrm{cm} 2 / \mathrm{nm}$ range. This type of lamp concentrates emitted light in a small 


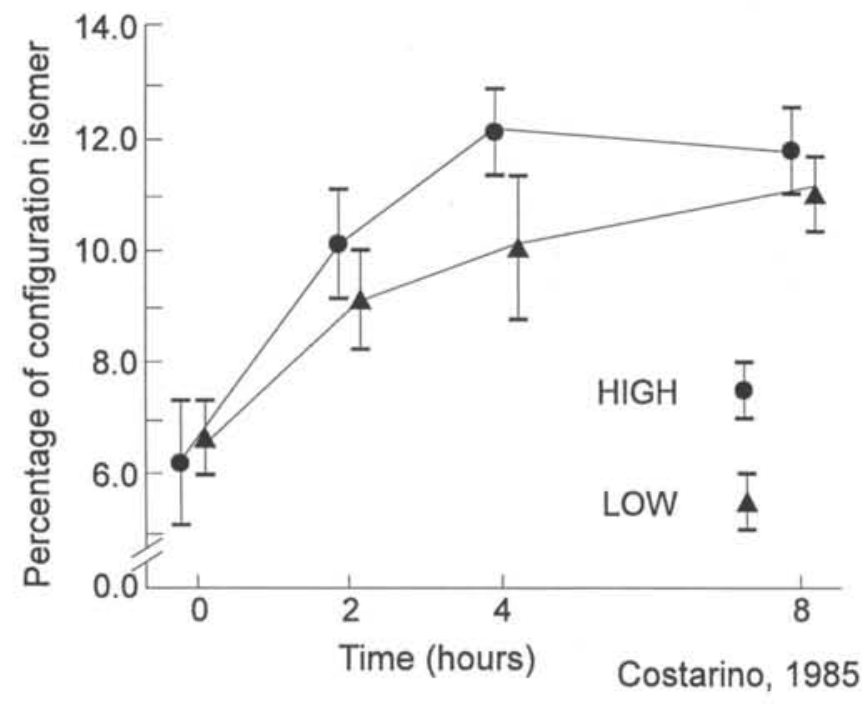

Figure 2 - Formation of the configuration isomer, according to irradiation.

and non-uniform area. ${ }^{31}$ COSTARINO et al. ${ }^{6}$ used a tungsten halogen lamp of $250 \mathrm{~W}$ on premature babies with physiologic jaundice, and noticed an increase in the formation of lumirubin when applied irradiation went from 6 to $12 \mathrm{mw} / \mathrm{cm} 2 / \mathrm{nm}$.

There is doubt as to the advantages and disadvantages of the side effects of high irradiations (higher than the previouly mentioned values), ${ }^{8,10,31}$ the type of filter used in the new equipment on the market, not to the mention the as at yet unkown side effects of this kind of lamp. Recently, HOLTROP et al. ${ }^{15}$ used moderate intensity halogen lamps, averaging $7 \mathrm{mw} / \mathrm{cm}^{2} /$ $\mathrm{nm}$, on low-weight newborn babies, and compared this treatment with traditional equipment utilizing

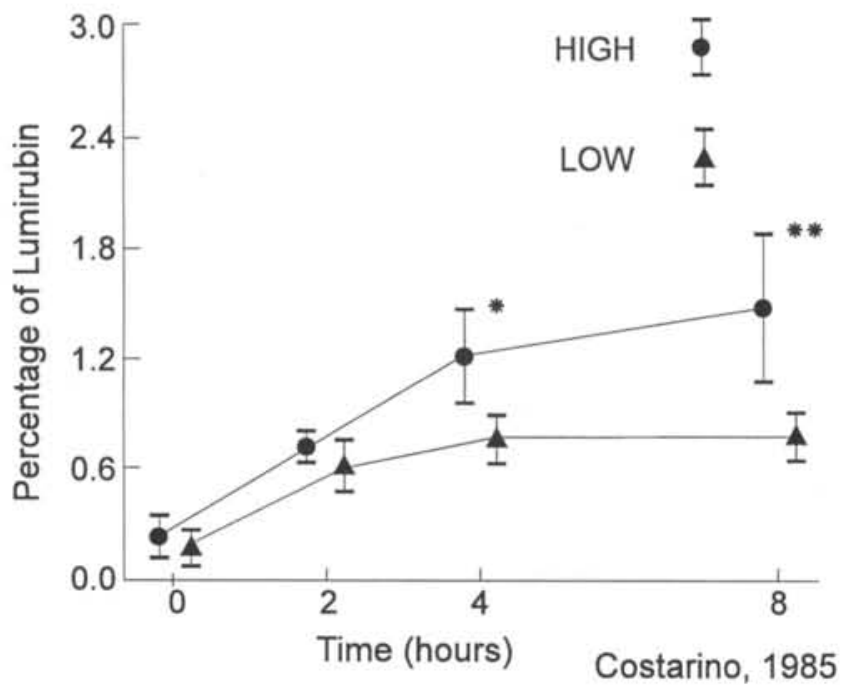

Figure 3 - Formation of Lumirubin, according to irradiation. fluorescent lamps. It would seem safer if we found out more about this type of lamp before using it routinely for phototherapy.

\section{Time of Use}

After 1 hour's use, white fluorescent lamps show an important decrease in irradiance of approximately 25 percent; ${ }^{4.18}$ after this, irradiance continues to decrease progressively and, at 2000 hours, is down to 44 percent of the initial irradiance. There is no precise data in several studies ${ }^{4.18 .26 .27}$ which could premit a final conclusion as to the ideal time for the use of the phototherapy lamps. Monitoring the efficacy of treatment and periodic measuring of irradiance utilizing appropriate equipment, which already exists on the market, may be more useful than frequent replacements of lamps.

\section{Color of the Light}

CRAMER originally used a set of 8 blue $40 \mathrm{~W}$ fluorescent lamps. ${ }^{26}$ Since then, several studies have been carried out to determine the best kind of lamp. However, studies vary greatly as to the type of gas used (iodine, fluoride, neon, tungsten), and as to the wattage and number of each lamp, which makes comparisons difficult. Green light has a higher wave length than the special blue; however, in vivo studies demonstrated that special blue may be a little better than green, although not much. ENNEVER deems there is no difference between the color of the lamps, and that blue light may not be as good as a conventional white lamp. Green light is less genotoxic because the wave length is greater than $450 \mathrm{~nm}$, and seems to penetrate the skin better than other light colors. ${ }^{8}$ There does not seem to be a confirmed better light color among the studies. ${ }^{8.9 .12 .27}$ Light with a wave length less than 350 $\mathrm{nm}$ is genotoxic and must be avoided; white light emits waves in this range and fiberglass protection must be used as a filter for this light spectrum. ${ }^{27}$

In summary, white light, which is the most widely employed and the most easily found, seems to be satisfactory, as long as energy emission is kept above 6 $\mathrm{mw} / \mathrm{cm}^{2} / \mathrm{nm}$.

\section{INTERFERENCE FACTORS}

Any object placed between the phototherapy equipment and the exposed surface may interfere with the 
efficacy of the therapy; thermal blankets, plastic bags (used to reduce body-heat loss in low-weight newborns), or an old, scratched incubator cover may diminish the efficacy of phototherapy. ${ }^{3.30}$

\section{OTHER TYPES OF PHOTOTHERAPY}

Neon blankets have been used on newborn babies with jaundice and studies have shown a similar or lower efficacy ${ }^{30.14}$ compared with traditional equipment, although there is the advantage of eliminating eye covering. ${ }^{14}$ However, more studies should be undertaken, especially on the oxidizing effects of light on bilirubin. In vitro studies have demonstrated an increase of the oxygen singlet free radical when light was placed three times closer to the body surface, contrary to studies with normal newborn babies in which these effects were less important.

\section{SIDE EFFECTS OF PHOTOTHERAPY}

Most of the adverse effects of phototherapy studied to date seem benign and temporary except perhaps for the genotoxic effect, ${ }^{5.19 .27}$ which has not yet been taken into consideration or measured sufficiently in clinical use. Recent studies, however, have demonstrated the effect of photo-oxidation on the membrane of erythrocytes, ${ }^{7.32 .33}$ suggesting that in those cases that already have a genetic

\begin{tabular}{l|c|c|c}
\hline & $\begin{array}{c}\text { Table 1 } \\
\text { Levels of indirect bilirubin that suggest } \\
\text { the use of phototherapy }\end{array}$ \\
\hline & \multicolumn{3}{c}{ Age in hours } \\
Birthweigh (g) & $>24 \mathrm{Hs}$ & $>48 \mathrm{Hs}$ & $>72 \mathrm{Hs}$ \\
\hline$>2500$ & 12 & 14 & 16 \\
$2001-2500$ & 10 & 12 & 14 \\
$1500-2000$ & 6 & 8 & 8 \\
$<1500$ & 6 & 6 & 6 \\
\hline
\end{tabular}

1) excludes cases of hemolytic disease.

2) in the presumption of factors such as perinatal hypoxia, acidosia, hyper or hypoglicemia, central nervous system abnomalitus, hypothermia or hypercapmia, reduce $2 \mathrm{mg} \%$. predisposition to membrane instability, as in spherocytosis, phototherapy should be used less. ${ }^{33}$ The use of phototherapy on infants with a deficiency of glucose-6phosphate dehydrogenase is controversial; ${ }^{19.33}$ however, there are studies that favor this treatment.

Riboflavin deficiency induced by phototherapy is now well-documented and can alter the short fatty acid beta-oxidation chain, thus limiting lipolysis in the liver, which is necessary for the energetic metabolism in the neonate period. Not all flavoenzymes are sensitive to phototherapy; however, riboflavin is the most susceptible to light. Riboflavin deficiency seems to be directly related to the duration of phototherapy, and to be enhanced in the premature infant. ${ }^{1.13}$ However, the significance of this metabolic alteration is not yet very clear. ${ }^{16.17 .24 .25}$

\section{WHEN TO USE PHOTOTHERAPY}

Newborns who weigh less than 1,500 or 2,000 grams have received prophylactic phototherapy from the moment of birth in several studies. These babies are, along with those who have isoimmunization hemolytic disease, considered today as those with the greatest risk of developing bilirubinic encephalopathy. ${ }^{2.5 .18 .26}$ In these lowweight newborns, phototherapy has diminished the need for an exsanguine transfusion, which should stimulate the use of the treatment. ${ }^{26}$ However, it is necessary to reflect on some facts: first, bilirubin levels may eventually be acceptable or even desirable for this kind of newborn, considering the anti-oxidizing power of bilirubin, which has a biological value in the newborn that is not yet known; second, the increased dehydration in newborns, which increases the peripheric blood flow, causing probable sacrifice to other areas. We therefore believe that prophylactic phototherapy, which is currently accepted and practiced, should undergo a rigorous and permanent reevaluation. It is also currently believed that the risk of encephalopathy is very low or virtually non-existent ${ }^{5.21}$. 22. 26 in healthy newborns without apparent hemolytic disease and weighing more than 2,500 grams, but who, however, present physiologic jaundice. MAISELS used phototherapy in the 1980's on these newborns at levels of $12 \mathrm{mg} / \mathrm{dl}$. Today the same author, ${ }^{21}$ acknowledging the new paths of research, considers, as do other authors, ${ }^{2.5 .22}$ that phototherapy is abused in these newborns. This overuse raises hospital expenses, separates babies from their mothers, and submits them to eventual iatrogenies without really evaluating the consequences of these acts. 
Our suggestions for the uses of phototherapy are in Table 1, excluding hemolytic diseases, because we believe phototherapy may be more liberally recommended in these cases than what is suggested by the table, due to its important role in reducing the need for exsanguine transfusions.

\section{DOES THE INDICATION OF}

PHOTOTHERAPY WITH HIGHER LEVELS IN HEALTHY TERM INFANTS CAUSE SIDE EFFECTS THAT ARE NOT DETECTED IN THE NEONATE PERIOD?

The United States National Institute of Child Health and Development has conducted a multicenter study of phototherapy on newborns with jaundice. ${ }^{23}$ In those weighing more than 2500 grams ( $140 \mathrm{NBs}$ ), phototherapy was used continuously whenever bilirubinemia was above $13 \mathrm{mg} / \mathrm{dl}$, with an average of $15 \mathrm{mg} / \mathrm{d}$. The babies were on average 60 -hours old. The equipment, the fluorescent daylight type, was used for 2000 hours at an average irradiance of $14 \mathrm{~mm} / \mathrm{cm}^{2} / \mathrm{nm}$; there was a significant decrease in the levels of bilirubinemia in newborns placed under phototherapy compared with the control group. However, this decrease was only significant in the first 24 hours of use $(2.3 \mathrm{mg} / \mathrm{dl}$ in the study group and $0.47 \mathrm{mg} / \mathrm{dl}$ in the control group) and did not interfere in the duration of the bilirubinemia in these newborn (Fig. 4). SCHEIDT ${ }^{29}$ and the other main investigators in this study followed these newborns for a period of 6 years to investigate their neuropsychologic and motor development, hearing and intelligence quotient. There was no significant difference amongst the newborns (with or without phototherapy) in any of these areas. The conclusion of the group was that phototherapy was efficient for the control of hyperbilirubinemia, with no evidence of adverse effects in six years of follow-up. PERLMAN, ${ }^{26}$ after critically analyzing this follow-up study, stated that it would be correct to say that jaundice with the phototherapy did not lead to greater brain damage than jaundice without phototherapy. This is in agreement with the newly-revised

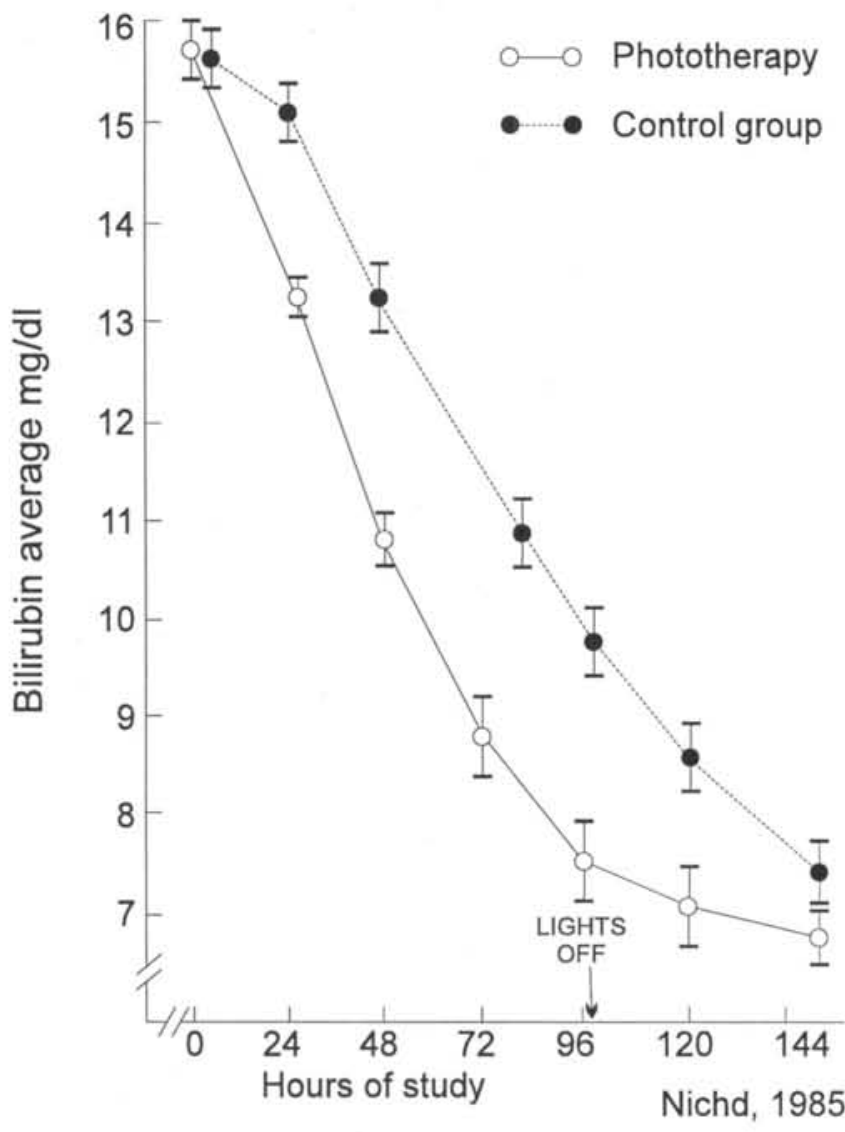

Figure 4 - Daily average of bilirubinemia in NBs in phototherapy and the control group; birth weight $\geq 2500 \mathrm{~g}$.

theories of bilirubinic encephalopathy, in which healthy, full-term infants (obviously without any sign of hemolytic disease) have a low risk of harm. ${ }^{21}$

Thus, we wish to emphasize the fact that recommendations for phototherapy must be stricter, since it seems to be overused in healthy, full-term newborns. It is absolutely essential, while using this method, to control the efficacy of the equipment by using an adequate number of lamps with irradiation within established standards, and by using filters to prevent genotoxic effects.

It is necessary to promote the adequate use, and prevent the abuse of phototherapy, in order to protect our patients from such an adequate method, which, when improperly used, could lose the credibility it has obtained in over thirty years of experience. 


\section{RESUMO}

O objetivo deste artigo é apresentar ao leitor os avanços nos conhecimentos sobre a fototerapia empregada em recémnascidos ictéricos. A eficácia desta forma terapêtica depende diretamente da intensidade de luz emitida pelos aparelhos e acredita-se que seja necessária uma dose entre 6 a $12 \mathrm{um} / \mathrm{cm} 3 /$ nanometro. Atualmente a indicaçăo da fototerapia tem sido questionada em recém-nascidos de termo e sadios, porém o uso adequado desta terapia deve ser preconizado até que se tenha um "concensus" sobre as vantagens e desvantagens do seu emprego.

\section{REFERENCES}

1. Amin HJ, Shukla AK, Snyder F, Fung E, Anderson NM, Parsons, HG. The signficance of phototherapy-induced riboflavin deficiency in the full-term neonate. Biol Neonate 1992;61:76-81.

2. Beaudry MA. The use of phototherapy for neonatal hyperbilirubinemia. CMAJ 1986;134:1237-45.

3. Caravalho M, Lopes JMA. Fototerapia nos hospitais públicos do Rio de Janerio. J Pediatria 1991;67(5/6):157-162.

4. Caravalho M, Lopes JMA. Qual é o tempo de vida útil de lâmpada fluorescentes para fototerapia? J Pediatria 1991;67(5/6):151-6.

5. Cockington RA. A guide to the use of phototherapy in the management of neonatal byperbilirubinemia. J Pediatric 1979;95(2):281-5.

6. Costarino A, Ennever JF, Buamgart S, Speck WT, Polin RA. Bilirubin photoisomerization in premature neonates under low- and high-dose phototherapy. Pediatrics 1985;75(3):519-22.

7. Deziel M, Girotti A. Photodynamic action of bilirubin on liposomes and erythrocyte membranes. J Biol Chem 1980;255(17):8192-6.

8. Ennever JF. Blue light, green light, white light, more light: Treatment of neonatal jaundice. Clin Perinatol 1990:17(2):467-81

9. Ennever JF, Knox I, Spec WT. Differences in bilirubin isomer composition in infants treated with green and white light phototherapy. J Pediatrics 1986;109:119-22.

10. Ennever JF. Phototherapy for neonatal jaundice. Photochem Photobiol 1988;47(6):871-6.

11. Ennever JF, Knox I, Denne CS, Spec WT. Phototherapy for neonatal jaundice: "in vivo"clearance of bilirubin photoproducts. Pediatr Res 1985;19(2):205-8.

12. Ennever JF. Phototherapy for neonatal jaundice. In: Polin RA, Fox WA, eds. Fetal and neonatal physiology. Philadelphia:W.B. Saunders, 1991:1165-72.
13. Gromish DS, Lopez R, Cole HS, Coperman JM. Light(phototherapy) induced riboflavin deficiency in the neonate. J Pediatrics 1977;90(1):118-22.

14. Holtrop PC, Madison K, Maisels JM. A clinical trail of fiberoptic phototherapy vs. conventional phototherapy. A J D C 1992;146:235-7.

15. Holtrop PC, Ruedizueli K, Maisels JM. Double versus single phototherapy in low birthweight newborns. Pediatrics 1992;5(5):674-7.

16. Lucas A, Bates, CJ. Transient riboflavin depletion in preterm infants. Arch Dis Child 1984;59:837-41.

17. Lucas A, Bates, CJ. Occurrence and significance of riboflavin deficiency in preterm infants. Biol Neonate 1987;52:113-8.

18. Maisels, MJ. In: Avery neonatology pathophysiology and management of the newborn, 3rd ed. Neonatal Jaundice. Philadelphia: J.B. Lippincott Co.,1987:534-629.

19. Meloni T, Corti R, Naitana AF, Arese P. The lack of effect of phototherapy on red cell riboflavin status and glucose6-phosphate dehydrogenase activity in normal and G-6-PFdeficient subjects with neonatal jaundice. J Pediatrics 1982;100(6):972-4.

20. McDonagh Af, Lightner DA. "Like a Shrivelled Blood Orange" - Bilirubin, jaundice, and phototherapy. Pediatrics 1985;75(3):443-54.

21. Newman T, Maisels MJ. Does hyperbilirubinemia damage the brains of healthy, full-term infants? Clin Perinatol 1990;117(2):331-57.

22. Newman T, Maisels MJ. Evaluation and treatment of jaundice in the term newborn: a kinder, gentler approach. Pediatrics 1992;89(5):809-18.

23. National Institute of Child Health and Human Development. The development of randomized, controlled trails of phototherapy for neonatal hyperbilirubinemia. Pediatrics 1985;75:385-441.

24. Parson HG, Dias VC. Intramitochondrial fatty acid metabolism: riboflavin deficiency and energy production. Biochem Cell Biol 1990;69:490-7. 
25. Patterson BE, Bates CJ, Halliday D, Lucas A. 1-13 Coctanoate oxidation, energy expenditure and vitamin B2 supplement in premature infants. Acta Paediatr Scand 1989;78:780-1.

26. Perlman M. The NICHD Phototherapy Study. Pediatrics 1990;86(5):811-12.

27. Polin RA. The Managment of neonatal hyperbilirubinemia: Rational use of phototherapy. Biol Neonate 1990;58(suppl):32-43.

28. Ramos JLA. Editoral. J Pediatrica 1991;67(5/6).

29. Scheidt P, Bryla D, Nelson KB, Hirtz DG, Hoffman HJ. Phototherapy for neonatal hyperbilirrubinemia: A sixyear follow-up of the National Institute of Child Health and Human Development Clinical Trial. Pediatrics 1990;85(4):455-63.
30. Stutchfield PR, Modi N, Weindling AM. Phototherapy and the use of heat shields in very low birthweight infants. Arch Dis Child 1988;63:552-4.

31. Tan KL. Phototherapy for neonatal jaundice. Clin Perinatol 1991;(3):423-39.

32. Tozzi E, Tozzi-Ciancarelli MG, Di Giulio A, D'Alfonso A, Farello G, Spennati GF, Matteis F. In vitro and in vivo effects of erythocyte phototherapy on newborns. Biol Neonate 1989;56:204-9.

33. Wong Wy, Powwars DR, Abdalla C, Wu PYK. Phototherapy failure in jaundice newborns with hereditary spherocytosis. Acta Paediatr Scand 1990;79:368-9. 